\title{
Labour activities of disabled people in the Russian Federation: features of legal regulation
}

\author{
Ruslan Madamindzhanovich Khakimov ${ }^{1^{*}}$, Igor Leonidovich Rudenko ${ }^{2}$, Galina Vasilievna \\ Martyanova $^{3}$, Alla Ignatovna Kairova ${ }^{4}$, and Natalya Valerievna Cherkashin ${ }^{3}$ \\ ${ }^{1}$ Moscow State University for the Humanities and Economics, Faculty of Law, Moscow, Russia \\ ${ }^{2}$ Moscow State University of Humanities and Economics, Faculty of Psychology and Pedagogy, \\ Moscow, Russia \\ ${ }^{3}$ Moscow State University for the Humanities and Economics, Department of Civil Law and \\ Procedure, Moscow, Russia \\ ${ }^{4}$ Moscow State University for the Humanities and Economics, Department of Theory and History of \\ State and Law, Moscow, Russia
}

\begin{abstract}
The purpose of the research is to provide a legal analysis of the labour activities of persons with disabilities in the Russian Federation. The authors consistently address employment issues of the persons with disabilities; also based on a review of Russian judicial practices, they formulate recommendations for the harmonisation of this vital area of labour relations. The research used the methods of system-oriented analysis, content analysis and comparative analysis. Based on the scientific analysis, the features and prospects of the development of legal regulation of employment of persons with disabilities were identified, and the comparative analysis method to identify areas of practice in the application of Russian federal and regional laws in Russia. At the beginning of the article, a historical excursion to the creation of the institution of labour relations with the involvement of persons with disabilities is provided; it starts from the second half of the 18th century until the end of the Soviet era, in the 1990s of the 20th century. Further, based on an analysis of the main legal instruments regulating the specified area of relations, the authors consider issues of the legislative consolidation of the procedure for quoting jobs for persons with disabilities, and also analyse the legal forms of protecting the labour rights of persons with disabilities and preventing discrimination on the basis of disability. Special focus is put on exercising control over the fulfilment by employers of the legal requirements concerning the provision of disabled people with jobs according to the established quota, as well as compliance with the related requirements established by sanitary rules. In Russia, the realisation of the right to work of disabled people is regulated not only at the federal but also regional level. Top priority is given to the regulation of labour relations involving disabled people and creation of the most favourable conditions for them in the constituent entities of the Russian Federation. In conclusion, the authors provide a list of proposals and recommendations for improving the
\end{abstract}

\footnotetext{
* Corresponding author: rmkhakimov.ru@gmail.com
} 
legal regulation of labour relations in the Russian Federation involving disabled people.

Keywords: right to work, legal regulation, rights of persons with disabilities, labour relations, job quotas, social obligations, human rights, disability discrimination, prohibition of discrimination

\section{Introduction}

The Russian Federation is a legal social state in which social problems are a major focus of interest. Certainly, one of them is the employment of disabled people.

The relevance of the research is due to a number of interrelated social and legal factors and, first of all, the high social problem of disability. All countries of the world and every group of society have people with disabilities. The number of them is significant and it keeps growing. The number of disabled people in Russia as of 01 April 2021 is 6,132,491 among women $(57 \%)$ and 4,688,234 among men $(43 \%)$ of the total population of the Russian Federation; and taking into account their family members, the topic of disability directly affects a quarter of the total population [1].

Despite the government's efforts, social policy towards people with disabilities is not sufficient; these efforts have a largely delayed effect, which increases the social stratification of Russians. In this context, a primary objective of the government is to carry out integration with less social difficulties for people with disabilities, for whom the level of social and labour adaptation is significantly reduced. Currently, it seems necessary to develop and pursue new state policy priorities focused on people with disabilities as far as labour relations are concerned. Such a policy should promote the principles of equal opportunities, focus bringing their life to normal and prohibiting discrimination.

By analysing the scientific literature on the issues in question, their narrow focus should be noted. Among the few analysed theses of legal, pedagogical and sociological focus, it is worth noting the scientific research of Gusev [2], Mozdokova [3], Tkachenko [4].

During the research, the regulatory documents of the Russian Federation, regional legislation and historical legalisations of the Russian Empire were widely used and analysed.

\section{$2 \quad$ Materials and methods}

The purpose of the research is to analyse the employment of people with disabilities in Russia and its legal regulation, identify legislative gaps in the implementation of the rights of people with disabilities in the world of work and promotion of the theoretical and practical mechanisms.

As part of the research, the following tasks were solved. The main stages of the history of regulation of labour relations of persons with disabilities were systematised; the key trends in the creation and legal regulation of the policy of equal opportunities in the field of employment in Russia and the regions were traced; based on the study of the regulatory framework and law enforcement practices, some problems of employment of people with disabilities in modern society and ways to solve them were identified.

Modern developments undoubtedly rely on the foundations created by the predecessors of modern scientists and researchers. By applying the historical research method, the development of labour legislation and its "echoes" in the modern regulation are considered. At the same time, methods of comparison and analysis are applied when studying the 
application of the existing law in regions and the Russian Federation as a whole. Also, a scientific and applied approach to study the conceptual apparatus in the field of regulation of labour relations for a certain category, namely disabled people. By applying these methods, the relationship between modern scientific achievements and legislative regulation of the employment of persons with disabilities is addressed.

\section{$3 \quad$ Results}

The contemporary Russian legislation concerning the employment of persons with disabilities is not fully implemented. In practice, some social barriers are encountered in the way of effective employment of persons with disabilities.

The analysis of the employment of people with disabilities in Russia can be clearly seen on the example of the statistical data presented in the tables below.

Table 1. Information about working disabled people [5].

\begin{tabular}{|l|c|c|c|c|c|c|c|c|}
\hline & 2014 & 2015 & 2016 & 2017 & 2018 & 2019 & 2020 & 2021 \\
\hline $\begin{array}{l}\text { People with disabilities, total, } \\
\text { thsd }\end{array}$ & 2,407 & 2,473 & 2,543 & 2,012 & 1,644 & 1,655 & 1,571 & 1,517 \\
\hline Group I, thsd & 82 & 82 & 82 & 69 & 49 & 53 & 40 & 41 \\
\hline $\begin{array}{l}\text { of which lifelong disabled } \\
\text { persons, thsd }\end{array}$ & 3 & 3 & 3 & 6 & 7 & 7 & 7 & 7 \\
\hline Group II, thsd & 913 & 923 & 939 & 704 & 557 & 556 & 525 & 472 \\
\hline $\begin{array}{l}\text { of which lifelong disabled } \\
\text { persons, thsd }\end{array}$ & 23 & 23 & 24 & 49 & 58 & 60 & 63 & 63 \\
\hline Group III, thsd & 1,409 & 1,466 & 1,520 & 1,235 & 1,038 & 1,046 & 1,006 & 1,004 \\
\hline $\begin{array}{l}\text { of which lifelong disabled } \\
\text { persons, thsd }\end{array}$ & 58 & 69 & 83 & 110 & 139 & 146 & 153 & 156 \\
\hline $\begin{array}{l}\text { Working disabled people in } \\
\text { the total number of disabled } \\
\text { people, \% }\end{array}$ & 19.1 & 19.8 & 20.5 & 16.9 & 14.3 & 14.7 & 14.0 & 13.9 \\
\hline
\end{tabular}

When reviewing the situation over time, it is noteworthy that until 2016 in Russia there was an annual increase in the number of employed people with disabilities, but since 2017 , the official statistics of the Russian Federation began to show a decrease in the number of working people with disabilities. This is due to the entry into force of the federal law dated 29 December 2015 No. 385-FZ "Suspension of certain provisions of regulatory instruments of the Russian Federation, amendments to certain regulatory instruments of the Russian Federation and the specifics of increased insurance pension, a flat-rate payment to the insurance pension and social pensions" providing for non-indexation of pensions for working pensioners [6].

In the dynamics of employment of persons with disabilities until 2017, there were multidirectional trends depending on the group of disabilities. According to I.V. Kalashnikova and A.A. Trinadtsatko, the increase in the proportion of employed persons with disabilities of Group 1 was due to a gradual decrease in their total number, approximately 50,000-70,000 per year [7].

In 2017, the Russian Federation Government approved an action plan to increase the employment rate of persons with disabilities in 2017-2020, which provided for an increase in the efficiency of employment services and the creation of conditions for expanding employment opportunities for persons with disabilities, which significantly increased their employment rates. 
The presented statistics make it possible for us to conclude that the employment rates of the disabled people are largely determined by the government's policy in this area, as well as by the general socio-economic situation in the country. This circumstance necessitates the adoption of effective statutory instruments that change the institutional conditions for the employment of persons with disabilities, which should be based on an assessment of the effectiveness of measures taken in the future.

\section{Discussion}

The peculiarities of employment of persons with disabilities have attracted the attention of scientists from overseas countries for a long time. In particular, certain aspects of the employment of people with disabilities were studied by scientists from Poland [8], Kazakhstan [9], Hungary [10], Moldova [11], Republic of Belarus [12] and other countries.

Issues of people with disabilities in the area of labour relations were the subject of regulation by the Russian state like in previous eras. The state took measures to create conditions for the employment of certain categories of persons with disabilities [13]. At first, disabled people were recruited to work in dedicated institutions created by the state, for example, by the decree of Empress Catherine II "Creation of public charity orders as part of provincial institutions" in each province of the Russian Empire, special bodies were set up - orders of public charity - in charge of the organisation and activities "workhouses" locally. In the second half of the 19th century, the so-called "houses of industriousness" were organized. In the "houses of industriousness" people with disabilities were provided with the necessary training followed by paid work.

Subsequently, employment became a full-fledged priority of the public policy and implied a series of medical, economic and organisational mechanisms for the realisation by disabled people of the right to work and protection of their health. The creation of the Soviet state significantly changed the country's political agenda. Able-bodied citizens of both sexes (from 16 to 55 years old) were required to get a job and work. In 1918, the workers' and peasants' government issued the Council of People's Commissars of the RSFSR [14]. This document guaranteed disabled citizens a pension that ensured their existence, in an amount that directly depended on the degree of disability. It is notable how precisely the early Soviet state defined disability - it was measured literally as a percentage. The state medical expert examination was responsible for that measurement. Only those persons, who were not able to work due to illness (congenital or acquired) or injury, were entitled to full exemption from labour service [15].

The labour activities of disabled people in the early 1930s became the focus of scientific analysis. In 1932, research institutes that focused on involving people with disabilities in the labour force were established. In addition, it was in the 1930s when special workshops appear for certain categories of disabled people on the basis of nosologies (pulmonary tuberculosis, diseases of the nervous system, visually impaired, etc.). The following important stage in promoting the realisation of the rights of persons with disabilities to work was associated with the adoption of the Constitution of the USSR in 1936. The 1936 Constitution recognised the right to work and pension for all citizens with disabilities irrespective of the type of disability and the cause of it [16]. Employment of people with disabilities in the post-war period primarily included their preliminary preparation for work, from supplying the necessary prostheses to short-term training.

During and after the Great Patriotic War, the number of people with disabilities in the USSR increased sharply as a result of the disablement of servicemen who were wounded during hostilities. Responsibility for the realisation of the right to work of persons who 
received the status of people with disabilities was entrusted to the People's Commissars by the decree of the Council of People's Commissars No. 640 "Employment of people with disabilities of the Patriotic War" [17]. In accordance with that document, workers with disabilities received both wages and pensions irrespective of the size of their previous income which significantly improved their financial situation.

The legislation on the regulation of labour relations with the participation of persons with disabilities was further developed in the 1971 Labour Code [18] which increased labour guarantees for persons with disabilities. This document brought to the legislative level the employer's obligation to hire people with disabilities and establish a special conditions specifically for them, for example, part-time work and other preferential working conditions in accordance with medical recommendations.

Contemporary Russian legislation, first of all, the Constitution prohibits discrimination at work [19]. In accordance with Article 3 of the Labour Code of the Russian Federation [20], Russian citizens may not have any advantages in labour relations including when applying for a job, including gender, age, other characteristics, if they are not related to the professional aptitude of an employee. Part 2 of the same article explains that it is not discrimination to establish any exceptions or preferences if they are related to the specifics of this type of labour activities and (or) are conditioned by the state's increased concern for persons in need of special legal and social protection.

With regard to persons with disabilities, who have restrictions on the performance of labour activities, the state guarantees them job quotas, that is, the employer's obligation to enter into an employment agreement with a certain number of applicants with disabilities, subject to the rule that it is possible to hire workers in excess of the quota, and less is unacceptable.

In accordance with Articles 20,21 of the federal law "Social Protection of Persons with Disabilities in the Russian Federation" for organisations, irrespective of organisational and legal forms and forms of ownership, the number of employees of which is more than 100 people, the legislation of the constituent entity of the Russian Federation establishes a quota for hiring disabled people - at least 2 and no more than 4 per cent of the average number of employees [21]. As for employers with the number of employees from 35 to 100 people, the constituent entities of the Russian Federation are not obliged but can set a quota for hiring people with disabilities in the amount of no more than $3 \%$ of the average number of employees. For example, in St. Petersburg, for organisations with more than 100 employees, a quota of $2.5 \%$ of the average number for employment of people with disabilities is established [22]. The effectiveness of the quota method in most regions of Russia is extremely low. Due to the lack of rigid control, employers do not pay the stipulated fines for evading quotas. Enterprises prefer to independently select employees from among vulnerable groups of the population for existing vacancies without using the services of employment centres. As a result, vulnerable individuals registered with the employment service remain unemployed [23].

The law "Employment of the Population in the Russian Federation" [24] was amended by the federal law No. 11-FZ dated 23 February 2013 [25] in accordance with which employers are obliged to provide monthly employment agencies with information on the availability of vacancies (positions), on the fulfilment of the quota for the employment of persons with disabilities, as well as on created or allocated workplaces for the employment of people with disabilities in accordance with a certain quota, inform the employment agencies about local regulations containing information about those workplaces.

For violation of the rights of persons with disabilities in the field of employment, namely for the employer's failure to fulfil the obligation to create or allocate jobs for the 
employment of persons with disabilities on the basis of the established quota, for the employer's refusal to hire persons with disabilities on account of the established quota by Article 5.42 of the Code of Administrative Offences of the Russian Federation for officials, administrative liability in the form of a fine from 5,000 to 10,000 roubles [26]. Moreover, the federal law of 23 February 2013, No. 11-FZ, the same liability was extended to officials of the employment agency of the Russian Federation for the unjustified refusal to register a person with disabilities as unemployed.

The working conditions for people with disabilities should meet individual rehabilitation or habilitation programmes. In addition, for people with disabilities of Groups I and II, reduced working arrangements are introduced - no more than 35 hours per week, subject to the preservation of full wages (Article 92 of the Labour Code of the Russian Federation). This rule does not seem fair enough, since in accordance with the Order of the Russian Ministry of Labour dated 27 August 2019 No. 585n "Classifications and criteria used in the implementation of medical and social examination of citizens by federal state institutions of medical and social examination" [27], Disability Group I can be characterised by a violation of human health with a persistent and significantly pronounced disorder of body functions caused by diseases, consequences of injuries or defects leading to a restriction of one of the following categories of life activities or their combination (ability to self-service; ability to move; to orientation; to communication; to control their behaviour; to learning and work activities).

A 35-hour working week should rather be established for people with disabilities of Groups II and III, and for Group I, the reduction in the number of working hours should be more significant (for example, up to 30 hours per week).

In accordance with Article 23 of the law "Social Protection of Persons with Disabilities in the Russian Federation", Articles 96, 99 and 113 of the Labour Code of the Russian Federation, persons with disabilities can be recruited to work at night, overtime work, to work on weekends and non-working holidays only if the following conditions are met:

It should be noted that in the area of job quotas for persons with disabilities, there are, in our opinion, some legal gaps that need to be addressed, namely:

- work should not be contraindicated for them in accordance with the medical assessment report;

- it is allowed to carry out such work only with their written consent;

- persons with disabilities should be informed in writing of their right to refuse the specified work.

Otherwise, such work should be considered as compulsory (Article 4 of the Labour Code of the Russian Federation), and for such a violation, the employer shall be brought to administrative responsibility under Article 5.27 of the Code of Administrative Offences of the Russian Federation.

The health status of working people with disabilities requires a longer time to recover physical, intellectual and mental costs; therefore, people with disabilities are provided with extended annual basic paid leave of 30 calendar days. In accordance with Article 128 of the Labour Code of the Russian Federation, persons with disabilities, upon their written application, are granted unpaid leave for up to 60 calendar days a year.

The health status of working people with disabilities requires a longer time to recover physical, intellectual and mental costs, therefore people with disabilities are provided with extended annual basic paid leave of 30 calendar days. In accordance with Article 128 of the Labour Code of the Russian Federation, disabled persons, upon their written application, are granted unpaid leave for up to 60 calendar days a year. 
- the federal legislation does not contain the concept of a quota, which causes difficulties in its calculation. The 1995 law does not disclose the concept of "quota". If we turn to the Recommendations on 1995 Quotas, which have now lost, then they understood the quota as the minimum number of jobs for citizens in particular need of social protection and experiencing difficulties in finding a job, which was determined as a percentage of the average number of employees of enterprises, institutions and organisations.

This definition of a quota is not entirely correct, since it does not allow calculating the number of jobs allocated as a quota if a fractional value is formed, i.e. federal law does not set rules for rounding fractional parts of numbers.

For example, with the maximum quota for the employment of people with disabilities at $4 \%$ and the minimum number of employees of the organisation, at which the quota is introduced, i.e. 101 people, as determined in the 1995 Law, the number of jobs will be 4.04 . It is obvious that it is impossible to employ a person with disabilities at 0.04 of a workplace;

- it should be noted that at present the level of quotas for people with disabilities has decreased: previously, the quota for hiring people with disabilities was set for entities exceeding 30 employees, and the percentage of quota jobs should have been at least 3 per cent.

If we compare the level of quotas in Russia and abroad, then it is much lower in Russia. For example, in Germany, every employer who employs more than ten employees is obliged to provide $6 \%$ of jobs for people with disabilities. In France, in enterprises with the same number of employees, $3 \%$ of the staff should be workers with disabilities and $10 \%$ war disabled veterans [28];

- in the 1995 Law, when establishing a quota, the statistical categories "number of employees" and "average number" of employees, on the basis of which the quota is established, are not used correctly. The number of employees is calculated as of a specific date. In fact, it is determined daily, including weekends and holidays.

Given the dynamism of labour resources in a market economy, the number of employees can, for a short period of time, for example, a month, repeatedly exceed 100 people and be less than this value, which makes it difficult to fulfil the quota, makes this category unsuitable for quotas and creates an opportunity for employers to evade the quota.

The category "average number of employees" is less dynamic, since it is determined by summing the number of employees on the payroll for each calendar day of the month and dividing the amount received by the number of those days. Therefore, it is more preferable;

- the federal law does not establish any features (requirements) in respect of jobs allocated on account of the quota.

The 1995 law does not take into account that quotas are carried out in relation to citizens who have a limited ability to work (they cannot be involved in work with harmful (hazardous) working conditions). For some citizens, it is required to create special jobs allowing employers to allocate either the lowest-paid jobs or jobs that are not suitable for the work of the corresponding category of citizens.

Therefore, when establishing a quota, it is necessary to use such criteria for the differentiation of labour as the industry affiliation of the employer, the nature of working conditions in the related production, the availability of specially equipped workplaces, etc. [29].

Thus, in the Russian Federation as a whole and in its regions separately, many regulatory documents aimed at exercising the right to work by persons with disabilities were adopted but not all of them are observed. Punishments for violation of the rights of 
persons with disabilities and the legal provisions in the area are too mild, and the powers of the regulatory authorities are too limited.

\section{Conclusion}

The state and society should be interested in adapting this social group so that people with disabilities can freely work in the profession that they consider most suitable for themselves. Employers should not remain indifferent to those people's problems. Enterprises should be supplied with custom equipment for people with disabilities, so that they feel like full-fledged people capable of working, so that they feel on an equal footing with healthy people. It is necessary to take into account the fact that it is economically more profitable for society and the state to have an employee with a disability - a taxpayer than a non-working disabled person - a dependent. All relevant services and departments, as well as the developed and existing legal provisions concerning the rights of persons with disabilities to work are aimed at this.

Priority should be given to the following measures to improve the employment of persons with disabilities:

- measures to design and adapt workplaces and work premises so that they are accessible to persons with various forms of disabilities;

- measures of support in the use of new technologies, development and production of auxiliary devices, fixtures, equipment and measures to facilitate the access of persons with disabilities to such means and equipment, so that they can get and keep a job;

- the state should organise and support companies that contribute to overcoming negative attitudes and prejudices towards employees with disabilities;

- the state as an employer should create favourable conditions for the employment of persons with disabilities in the public sector;

- measures to maximise the involvement of persons with disabilities in the development of training programmes and employment programmes in the private and non-governmental sectors should be taken;

- the state and organisations, employers should cooperate with organisations of persons with disabilities in all efforts taken to create opportunities for training including the establishment of flexible working hours, part-time work and job splitting.

To eliminate the problems identified in the Russian Federation, the following solutions are proposed: to conduct an annual monitoring of employment at workplaces equipped for people with disabilities and determine the level of need for people with disabilities in employment; it is necessary to develop centres of assistance in the employment of students and graduates with disabilities, at public or municipal organisations of vocational education; to strengthen the interaction of educational authorities and employment agencies with medical and social assessment institutions as well as social welfare bodies in order to implement an individual programme for the rehabilitation and habilitation of a person with disabilities; to ensure that tax incentives can be provided for employers with employees with disabilities; to toughen employers' liability for refusing to hire a disabled person within the established quota; make the above changes to the existing Russian law, specify the provisions concerning job quotas for people with disabilities, in the Labour Code of the Russian Federation; combining miscellaneous provisions on labour relations with the involvement of persons with disabilities, add a separate chapter "Peculiarities of regulation of labour of persons with disabilities". 


\section{References}

1. Chislennost invalidov [Number of people with disabilities]. Accessed on: October 17, 2021. [Online]. Available: https://sfri.ru/analitika/chislennost

2. A.Yu. Gusev, Sudebnaya zashchita prava rossiiskikh grazhdan na sotsialnoe obespechenie [Judicial protection of the right of Russian citizens to social security] Abstract of a PhD thesis in Legal Science (The Institute of State and Law of the Russian Academy of Sciences, Moscow, 2017)

3. Yu.S. Mozdokova, Kommunikativno-deyatelnostnyi podkhod k integratsii invalidov: sotsialno-kulturnyi aspekt [Communicative-activity approach to the integration of disabled people: social and cultural aspect], Abstract of a $\mathrm{PhD}$ thesis in Pedagogic Sciences (Moscow State University of Culture and Arts, Moscow, 2006). Accessed on: October 17, 2021. [Online]. Available: https://static.freereferats.ru/_avtoreferats/01003319584.pdf

4. V.S. Tkachenko, Integratsiya v rossiiskom obshchestve lyudei s invalidnostyu [Integration of people with disabilities in the Russian society] Abstract of a PhD thesis in Sociology (North-Caucasus State Technical University, Stavropol, 2007. Accessed on: October 17, 2021. [Online]. Available:

https://www.dissercat.com/content/integratsiya-v-rossiiskom-obshchestve-lyudei-s-inv alidnostyu

5. Polozhenie invalidov [The situation with the disabled people]. Accessed on: October 17, 2021. [Online]. Available: https://rosstat.gov.ru/folder/13964

6. A.A. Voropaev, Young Res, 17(307), 341-346 (2020)

7. I.V. Kalashnikova, A.A. Trinadsadko, Newsl Pacific State Univ, 1(44), 141-154 (2017)

8. M. Garbat, Econ Trends, 1, 17-25 (2017)

9. M.M. Yessirkepova, R. M. Anarova, Newl Gumilyov Euras Nation Univ. Ser: Law, 3(128), 127-136 (2019). https://doi.org/10.32523/2616-6844-2019-128-3-127-136

10. E.O. Olabisi, Polish J Sci, 26-2(26), 3-6 (2020)

11. E. Aculai, L. Saghin, Econ Soc: Theor Sci J, 1, 31-42 (2020). https://doi.org/10.36004/nier.es.2020.1-03

12. I.A. Komotskaya, Labour Soc Law, 4(32), 39-42 (2019)

13. N.V. Cherkashina, A.V. Ognev, Int Res J, 5-3(107), 109-114 (2021)

14. Dekret SNK RSFSR ot 31.10.1918 "Polozhenie o sotsialnom obespechenii trudyashchikhsya" [Decree of the Council of People's Commissars of the RSFSR of 31.10.1918 "Regulations on social security of workers"]. Accessed on: October 17, 2021. [Online]. Available:

http://www.consultant.ru/cons/cgi/online.cgi?req=doc\&base=ESU\&n=4478\#NBWHJf S4id1oTqs02

15. Sobranie uzakonenii i rasporyazhenii rabochego i krestyanskogo pravitelstva. Statya 905. Kodeks zakonov o trude [Collection of laws and regulations of the workers' and Peasants' government. Article 905. Labor Code]. Accessed on: October 17, 2021. [Online]. Available: https://vcpi.nlb.by/static/pdf/kodexy-BSSR/st_905_kodeks_zakonov_o_trude.pdf 
16. Konstitutsiya (Osnovnoi zakon) Soyuza Sovetskikh Sotsialisticheskikh Respublik (utverzhdena postanovleniem Chrezvychainogo VIII Syezda Sovetov Soyuza Sovetskikh Sotsialisticheskikh Respublik ot 5 dekabrya 1936 g.) [Constitution (Basic Law) of the Union of Soviet Socialist Republics (approved by the resolution of the Extraordinary VIII Congress of Soviets of the Union of Soviet Socialist Republics of December 5, 1936)]. Accessed on: October 17, 2021. [Online]. Available: https://constitution.garant.ru/history/ussr-rsfsr/1936/red_1936/3958676/

17. Postanovlenie ot 6 maya 1942 g. No. $640 \mathrm{O}$ trudovom ustroistve invalidov otechestvennoi voiny [Resolution of May 6, 1942 no. 640 On the labor arrangement of the disabled of the patriotic war] Accessed on: October 17, 2021. [Online]. Available: https://www.alppp.ru/law/trud-i-zanjatost-naselenija/trud/151/postanovlenie-snk-sssr-ot -06-05-1942--640.html

18. “Kodeks zakonov o trude Rossiiskoi Federatsii” (utv. VS RSFSR 09.12.1971) (red. ot 10.07.2001, s izm. ot 24.01.2002) ["The Labor Code of the Russian Federation" (approved by the Supreme Council of the RSFSR on 09.12.1971) (ed. of 10.07.2001, with amendments. from 24.01.2002)] Accessed on: October 17, 2021. [Online]. Available: http://www.consultant.ru/document/cons_doc_LAW_1035/

19. "Konstitutsiya Rossiiskoi Federatsii” (prinyata vsenarodnym golosovaniem 12.12.1993 s izmeneniyami, odobrennymi v khode obshcherossiiskogo golosovaniya 01.07.2020) ["Constitution of the Russian Federation" (adopted by popular vote on 12.12.1993 with amendments approved during the all-Russian vote on 01.07.2020)]. Accessed on: October 17, 2021. [Online]. Available: http://www.consultant.ru/document/cons_doc_LAW_28399/

20. "Trudovoi kodeks Rossiiskoi Federatsii" ot 30.12.2001 No. 197-FZ (red. ot 28.06.2021, s izm. ot 06.10.2021) (s izm. i dop., vstup. v silu s 01.09.2021) ["Labor Code of the Russian Federation" dated 30.12.2001 No. 197-FZ (ed. dated 28.06.2021, with amendments. from 06.10.2021) (with amendments and additions, intro. effective from 01.09.2021)]. Accessed on: October 17, 2021. [Online]. Available: http://www.consultant.ru/document/cons_doc_LAW_34683/

21. Federalnyi zakon "O sotsialnoi zashchite invalidov v Rossiiskoi Federatsii" ot 24.11.1995 No. 181-FZ (poslednyaya redaktsiya) [Federal Law "On Social Protection of Disabled Persons in the Russian Federation" dated 24.11.1995 No. 181-FZ (latest edition)]. Accessed on: October 17, 2021. [Online]. Available: http://www.consultant.ru/document/cons_doc_LAW_8559/

22. O kvotirovanii rabochikh mest dlya trudoustroistva invalidov v Sankt-Peterburge (s izmeneniyami na 19 fevralya 2020 goda) [On the quota of jobs for the employment of disabled people in St. Petersburg (as amended on February 19, 2020)]. Accessed on: October 17, 2021. [Online]. Available: http://docs.cntd.ru/document/8377307

23. N.V. Gashenina, Regionology, 3(60), 222-227 (2007)

24. Zakon RF "O zanyatosti naseleniya v Rossiiskoi Federatsii” ot 19.04.1991 No. 1032-1 (poslednyaya redaktsiya) [The Law of the Russian Federation "On employment of the population in the Russian Federation" dated 19.04.1991 No. 1032-1 (latest edition)]. Accessed on: October 17, 2021. [Online]. Available: http://www.consultant.ru/document/cons_doc_LAW_60/

25. Federalnyi zakon "O vnesenii izmenenii v otdelnye zakonodatelnye akty Rossiiskoi Federatsii po voprosu kvotirovaniya rabochikh mest dlya invalidov" ot 23.02.2013 No. 11-FZ (poslednyaya redaktsiya) [Federal Law “On Amendments to Certain Legislative 
Acts of the Russian Federation on the Issue of job Quotas for disabled people" dated 02/23/2013 No. 11-FZ (latest edition)]. Accessed on: October 17, 2021. [Online]. Available: http://www.consultant.ru/document/cons_doc_LAW_142512/

26. "Kodeks Rossiiskoi Federatsii ob administrativnykh pravonarusheniyakh" ot 30.12.2001 No. 195-FZ (red. ot 01.07.2021) (s izm. i dop., vstup. v silu s 01.10.2021) ["The Code of the Russian Federation on Administrative Offenses" of 30.12.2001 No. 195-FZ (ed. of 01.07.2021) (with amendments and additions, intro. effective from 01.10.2021)]. Accessed on: October 17, 2021. [Online]. Available: http://www.consultant.ru/document/cons_doc_LAW_34661/

27. Prikaz Ministerstva truda i sotsialnogo razvitiya RF ot 27 avgusta 2019 g. № 585n “O klassifikatsiyakh i kriteriyakh, ispolzuemykh pri osushchestvlenii mediko-sotsialnoi ekspertizy grazhdan federalnymi gosudarstvennymi uchrezhdeniyami mediko-sotsialnoi ekspertizy" [Order of the Ministry of Labor and Social Development of the Russian Federation No. 585n dated August 27, 2019 "On classifications and criteria used in the implementation of medical and social expertise of citizens by Federal state institutions of medical and social expertise"]. Accessed on: October 17, 2021. [Online]. Available: https://www.garant.ru/products/ipo/prime/doc/72921006/

28. I.Ya. Kiselev, Sravnitelnoe i Mezhdunarodnoe trudovoe pravo [Comparative and International Labour Law] (PRIOR, Moscow, 1999)

29. Yu.B. Korsanenkova, Labor Law Rus Abroad, 2, 23-27 (2010) 